\title{
Structural setting of the Koum sedimentary basin (north Cameroon) derived from EGM2008 gravity field interpretation
}

\author{
Yves SHANDINI ${ }^{1,2}$, Patrice Arnaud KOUSKE 3 , Severin NGUIYA ${ }^{4}$, \\ Mouzong Pemi MARCELIN ${ }^{1,5}$ \\ ${ }^{1}$ Department of Physics, Faculty of Science, University of Yaounde I, Cameroon \\ ${ }^{2}$ Department of Oceanology and Limnology, Institute of Fisheries and Aquatic Sciences \\ at Yabassi, The University of Douala, Cameroon; e-mail: shandiniyves@gmail.com \\ ${ }^{3}$ Institute of technology, University of Douala, Cameroon; e-mail: arnaudpatricek@yahoo.fr \\ ${ }^{4}$ Faculty of Industrial Engineering, University of Douala, Cameroon; \\ e-mail: nguiyaplus@yahoo.fr \\ ${ }^{5}$ Higher Technical Teacher's Training College, Department of Renewable energy, \\ University of Buea, Cameroon; e-mail: mouzong.pemi@ubuea.cm
}

\begin{abstract}
This study is a contribution to the planning of hydrocarbon exploration program of the Koum sedimentary basin in North Cameroon. 3D modeling of WGM2012 gravity data derived from EGM2008 geopotential model in the Koum basin was used together with existing geological and spectral analysis information to give structural picture of the basin. The 3D model of the Koum basin confirms that the basin is developed as a half graben bounded by sub-vertical faults. The thickness of the Cenozoic sediments is about $1.5 \mathrm{~km}$ in the eastern part and reaches $4.5 \mathrm{~km}$ in the western part of the basin. Gravity lineaments computed by multi-scale analysis revealed structural trends in the $\mathrm{E}-\mathrm{W}, \mathrm{NW}-\mathrm{SE}, \mathrm{NE}-\mathrm{WS}$ and $\mathrm{N}-\mathrm{S}$ directions. The faults in the sedimentary terrain reach $6 \mathrm{~km}$ depth and have a predominant NW-SE trend with E-W trending faults along the contact between the sedimentary section and the basement complex in the northern edge.
\end{abstract}

Key words: Koum sedimentary basin, 3D density model, spectral analysis, horizontal gradient, faults

\section{Introduction}

In view of investigating new sources of oil and gas, Cameroon envisages to conduct exploration of hydrocarbon resources of onshore sedimentary basins 
(Koum, Mamfe and Garoua). Even though geological and geophysical exploration activities in Cameroon started more than 50 years ago, geology of these basins is relatively unknown compared with the coastal basins. The Koum basin which is the largest of the isolated Cretaceous basins in the north Cameroon region has been poorly studied because of its relative inaccessibility and thus is poorly covered by the country geophysical database.

In this paper we present the subsurface structure setting of the Koum sedimentary basin using gravity data extracted from the World Gravity Map (WGM 2012) database (Bonvalot et al., 2012; Balmino et al., 2012) derived from the EGM2008 geopotential model. Gravity method is one of the best geophysical techniques for delineating subsurface structures and is widely used in hydrocarbon exploration to establish the limits and structure of sedimentary basins. In this work, a constrained 3D density model of the upper crust in the Koum basin area was obtained based on Bouguer anomaly data by means of modelling and inversion. Multi-scale analysis was also applied to obtain a map of the geological contacts and deep faults in the area. This study is a contribution to the planning of hydrocarbon exploration program of the Koum basin since the appraisal of the basin subsurface structure can allow the delineation of areas with large sedimentary thickness which are believed to be areas of possible hydrocarbon exploration targets and since, in general, fractures and faults within a reservoir can provide important pathways for the movement of reservoir fluids.

\section{Geological and tectonic settings}

The Koum basin also called Mayo Rey basin is located in the northern region of Cameroon between latitudes $8^{\circ} 11^{\prime}$ and $8^{\circ} 20^{\prime}$ and longitudes $14^{\circ} 11^{\prime}$ and $15^{\circ}$. The Koum basin stretches over $80 \mathrm{~km}$ long by $16 \mathrm{~km}$ wide (Brunet et al., 1988; Brunet et al., 1990; Maurin et al., 1986; Schwoerer, 1965) and covers a total surface area of about $1200 \mathrm{~km}^{2}$. The Koum basin is a relatively small half-graben, located about $25 \mathrm{~km}$ to the southeast of outcrops of Yola Arm and Benue through (Popoff, 1988) (Figs. 1 and 2) filled primarily by sediments of Cretaceous age covered by thin ferruginous hardground and recent alluviums (Duperon-Laudoueneix, 1991; Brabant, 1976; Brabant and Gavaud, 1985). Popoff (1988) proposed that the Koum basin were part of 


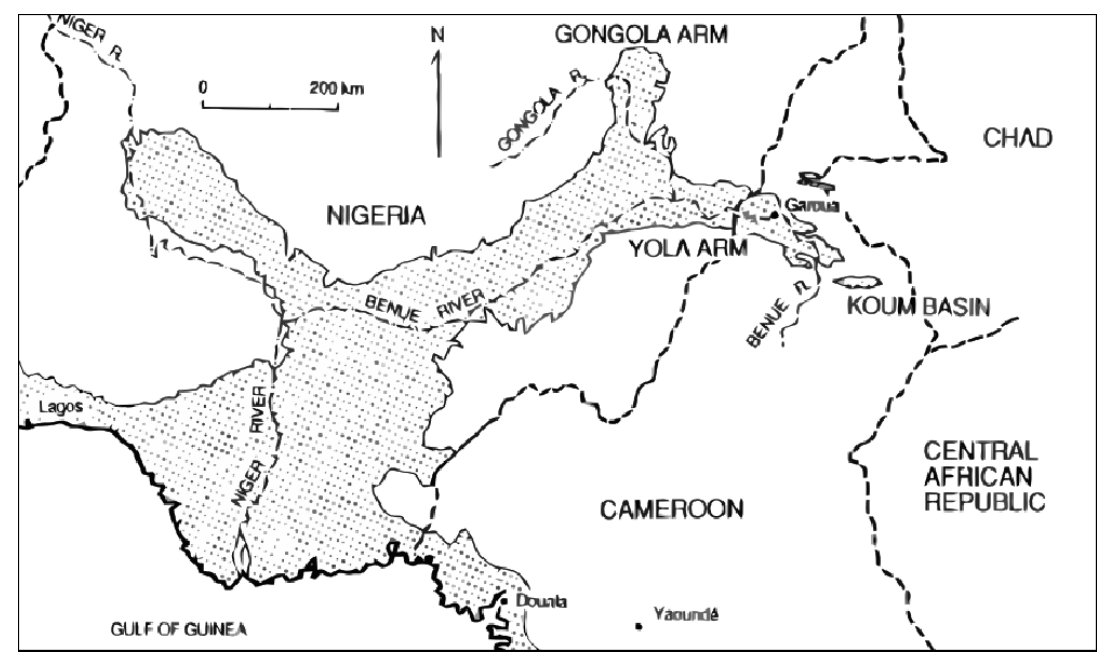

Fig. 1. Distribution of cretaceous and younger sediments in the Benue trough (after Allix and Popoff, 1983).

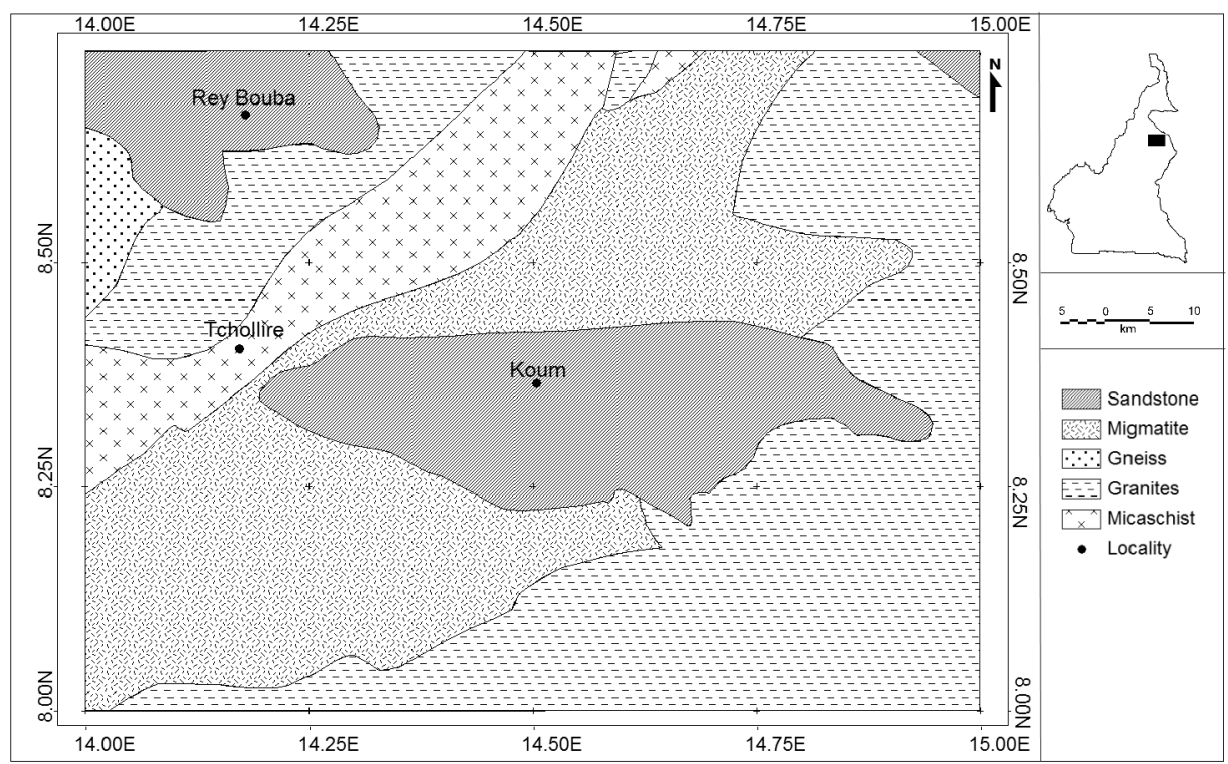

Fig. 2. Geological sketch map of the Koum basin. 
an early episode of rifting associated with $\mathrm{N}-\mathrm{S}$ extensional regime which existed prior to inception of the Benue trough proper. Brunet et al. (1990) also implicate the Koum basin in an early episode of rifting which preceded the formation of the main part of the Benue trough. The geologic map of Schwoerer (1965) shows Yola Arm sediments to be similar in age to those in the Koum basin. He grouped the Koum basin rocks with those of the Logone and Benoue Basins, defining their age as "Cretace Moyen".

\section{Database and gravity field features}

The Bouguer gravity data for the study area has been acquired from the World Gravity Map (WGM 2012) database (Bonvalot et al., 2012; Balmino et al., 2012). WGM 2012 gravity data is available all over the globe, has no gaps and therefore can provide suitable data for geological and geophysical applications in areas lacking surface gravity measurements. The WGM 2012 Bouguer data is derived from the EGM2008 geopotential model (Pavlis et al., 2012) and is computed at the Earth's surface with a $1^{\prime} \times 1^{\prime}$ resolution. The EGM2008 geopotential model was developed by the National Geospatial-Intelligence Agency (NGA) and includes surface gravity measurements (from land, marine or airborne surveys), satellite altimetry and satellite gravimetry (GRACE mission) measurements. Technical specifications on EGM 2008 gravity fields can be found in National GeospatialIntelligence Agency (NGA) website: http://earth-info.nga.mil/GandG/ wgs84/gravitymod/egm2008.

The available WGM 2012 Bouguer gravity data of the Koum area is presented as a $5 \mathrm{mGal}$ contour map (Fig. 3). The reference density used for the Bouguer anomaly map of the study area is $2670 \mathrm{~kg} / \mathrm{m}^{3}$ and projection information: UTM, zone 33, spheroid and datum WGS 84 .

In situ Bouguer gravity data of the survey area (Collignon, 1968) have been extracted from the ORSTOM (Office de la Recherche Scientifique et Technique Outre-Mer) database and compared with the Bouguer gravity data generated using EGM2008. The raw gravity data study was acquired with the Worden or Lacoste and Romberg gravimeters with a resolution of $0.01 \mathrm{mGal}$. They were collected at about $4 \mathrm{~km}$ intervals between gravity stations, on all available roads and tracks in the area (Fig. 3). All 
gravity measurements were tied to the International Gravity Standardization Network 1971 (IGSN71) datum after correction of luni-solar effect and instrumental drift. The measurement accuracy was about $0.5 \mathrm{mGal}$. To determine the Free-Air anomaly, the linear vertical gradient of $0.3086 \mathrm{mGal} / \mathrm{m}$ was used to approximate free-air correction. Elevation values were obtained with Wallace and Tiernan altimeters. A correction density of $2670 \mathrm{~kg} / \mathrm{m}^{3}$ was used for the Bouguer correction. The statistics of the differences of in situ and EGM2008 Bouguer gravity anomalies for the study area are given in Table 1.

Table 1. In situ vs EGM2008 Bouguer gravity data differences.

\begin{tabular}{|l|r|}
\hline Number of values & 129 \\
\hline Minimum & $3.66 \mathrm{mGal}$ \\
\hline Maximum & $26.93 \mathrm{mGal}$ \\
\hline Mean & $14.51 \mathrm{mGal}$ \\
\hline Standard deviation & $3.59 \mathrm{mGal}$ \\
\hline
\end{tabular}

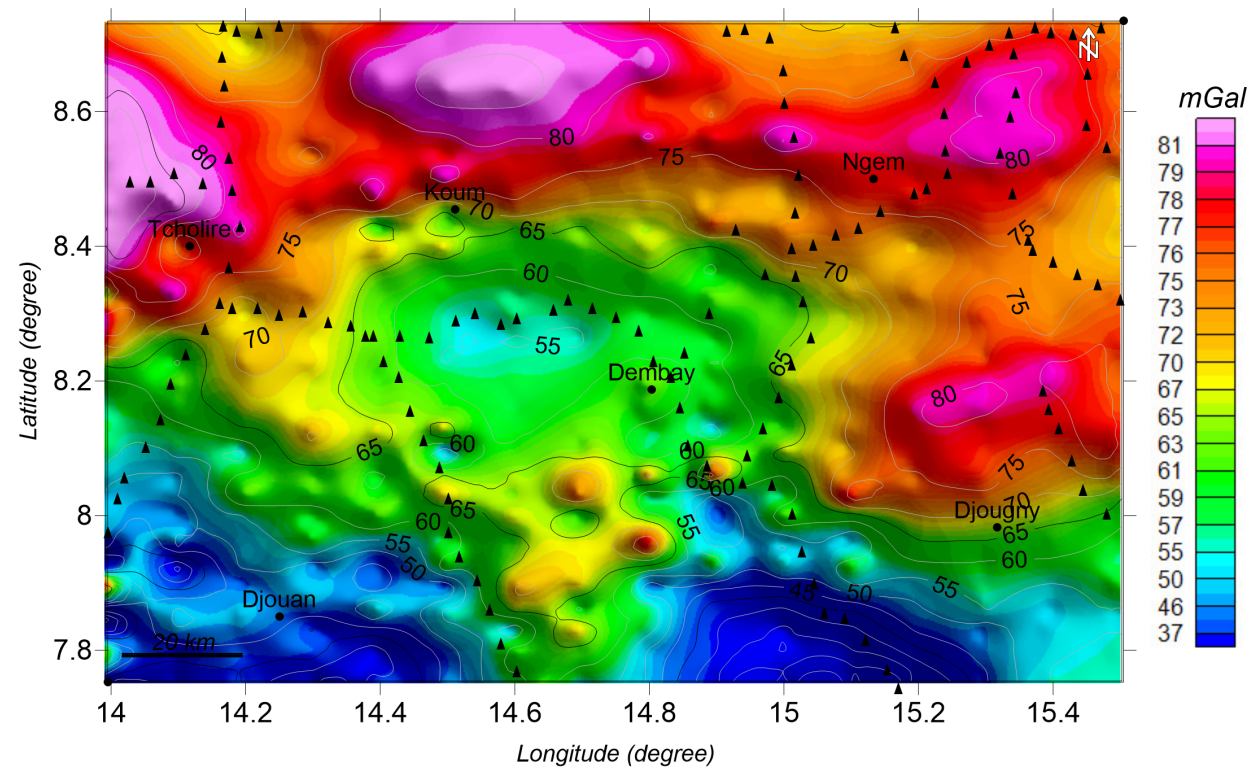

Fig. 3. Bouguer Gravity map of the Koum area. Black triangles show the ground gravity stations. 
On the Bouguer gravity map, the Cenozoic sediments of Koum basin are characterized by a long-wavelength gravity low which reaches a minimum value of $55 \mathrm{mGal}$ in the central part of the Bouguer map. The northern, western and eastern parts of the map show gravity highs of about $82 \mathrm{mGal}$ associated to Precambrian basement rocks. The southern area of the map is characterized by gravity lows reaching $35 \mathrm{mGal}$. The southern negative anomalies don't correlate with surface geology (granite bodies and metamorphic rocks) and thus can be interpreted as gravitational effect of a deep tectonic depression in the southern part of the basin. The central negative anomaly is bounded by relatively steep gradients in the northern, western and eastern edges. It can be inferred that the Koum basin is a half graben bounded by faults in the northern, western and eastern edges.

\section{Bouguer anomaly regional/residual separation}

This study is based on qualitative and quantitative analysis of the Bouguer gravity data to delineate basement structure of the Koum basin area. Regional/Residual separation was made using polynomial method to isolate deep source from shallow sources. Zeng's technique (Zeng, 1989) was applied to determine the degree of the polynomial that gives the most efficient estimation of the regional trend from the Bouguer anomaly data. To apply the Zeng's technique:

- Bouguer gravity data were upward-continued at different levels by step of $5 \mathrm{~km}$ up to $60 \mathrm{~km}$ and the number of extremes counted,

- the number of extremal points of the calculated upward continuation map was plotted against the corresponding level of continuation (Fig. 4a). From Fig. 4a, it is seen that, for $h \geq 25 \mathrm{~km}$, the number of extreme points of the anomaly contour map at different heights is approximately constant.

The polynomials of degree $1,2, \ldots, 10$ have been fitted to the upward continuation map at height $h_{m}=25 \mathrm{~km}$ and as a result, a graph of variance against the polynomial degree is plotted (Fig. 4b). The optimum upward continuous height of $25 \mathrm{~km}$ obtained to determine the regional trend from 

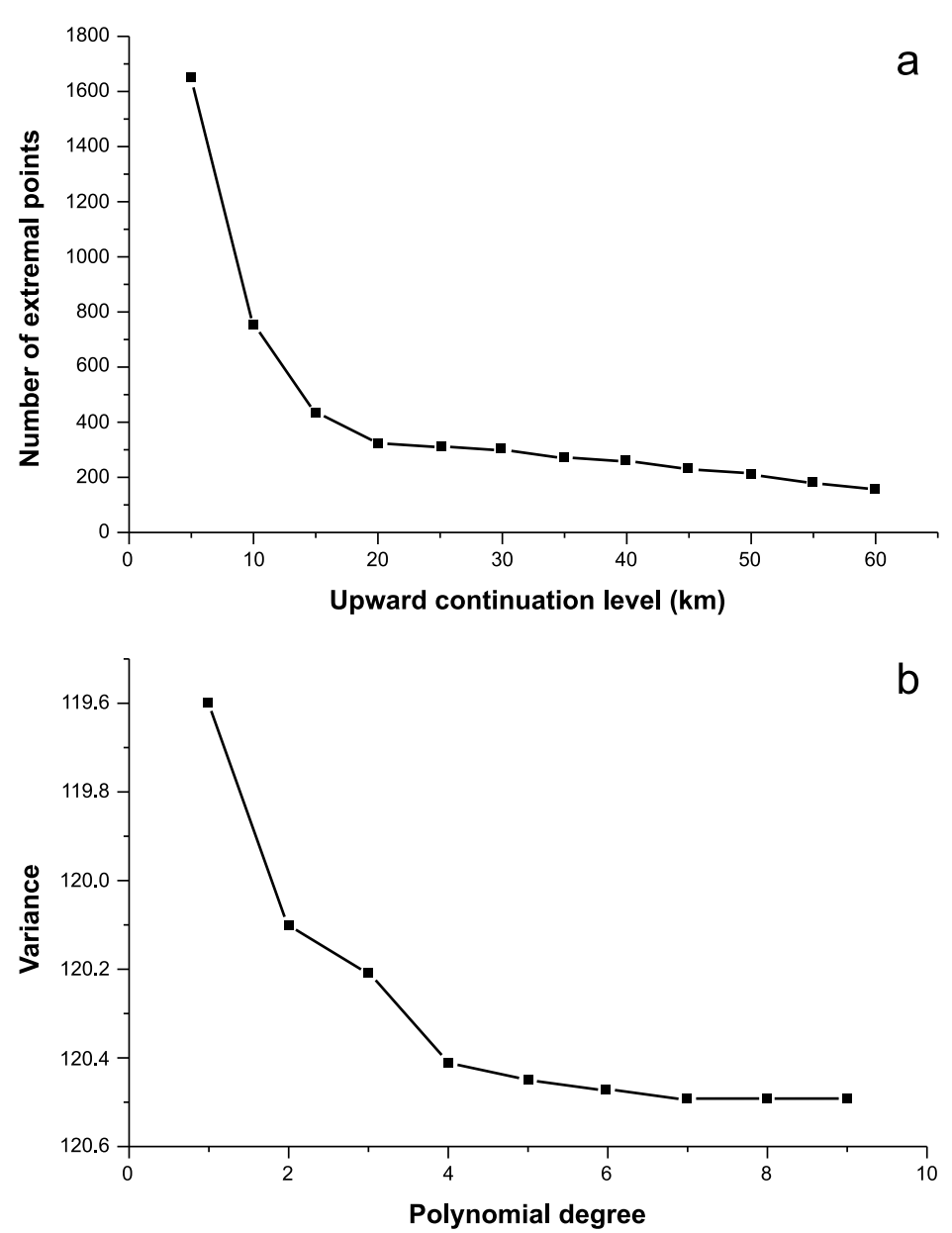

Fig. 4. a) graph of variation of the number of extrema according to the upward continuation height, b) graph of the variance according to the degree of the polynomial.

the Bouguer anomaly data is consistent with the results of deep seismic investigations by Tokam et al. (2010) who find a crustal thickness of $25.5 \mathrm{~km}$ in the South of Yola through. The appropriate degree of the regional polynomial is estimated from the point of gradient turning point on this graph. Accordingly, the optimum degree of polynomial representing the upward continuation of the observed anomaly at height $h_{m}=25 \mathrm{~km}$ is four. 
The regional structure (Fig. 5) is characterized by a gradient decreasing towards the south possibly indicating crustal thickening. The variations on the regional anomaly can be interpreted as the undulations of the Moho. This map indicates that the Mohorovicic discontinuity is rising northward.

The regional component was subtracted from the Bouguer map to obtain the residual map (Fig. 6). On the residual map the gravity low associated to the sedimentary formations is more pronounced and enable to better delimit the extension of the basin with a possible reservation, namely that some part of the gravity signal coming from the basin infill can be still included also in the regional gravity anomaly map which, unfortunately, is and will remain a week point of the polynomial method of regional/residual separation.

\section{Tectonic trend analysis}

To extract deep faults in the study area, multi-scale edge analysis was performed on WGM2012 Bouguer gravity dataset. Bouguer gravity data were firstly upward-continued at different levels 2, 4, 6, 8, 10 and $12 \mathrm{~km}$. Horizontal gradient maxima of upward-continued data at different levels were calculated and plotted (Fig. 7).

In 2D top view, the linear features defined by the succession of points are related to the trend of the deep faults in the area and these faults are traced along these salient features. The resulting set of lineaments is shown in Fig. 8. The horizontal derivative of gravity anomalies is maximum over the boundaries of geological structures like horst or graben, masses extending horizontally and vertically, fault blocks and volcanic intrusive bodies (Blakely, 1995).

The lineaments in the study area are shown in Fig. 8. The basement terrains tend to have the greater number of lineaments than in the sedimentary terrain. The rose diagram for all the lineaments mapped in the study area is shown in Fig. 9. The predominant trends of the lineaments are $\mathrm{E}-\mathrm{W}, \mathrm{NW}-\mathrm{SE}, \mathrm{NE}-\mathrm{WS}$ and $\mathrm{N}-\mathrm{S}$. The faults in the sedimentary terrain have a predominant NW-SE trend with $\mathrm{E}-\mathrm{W}$ trending faults along the contact between the sedimentary section and the basement complex at the latitude of Koum town. The horizontal gradient maxima map in the basin 


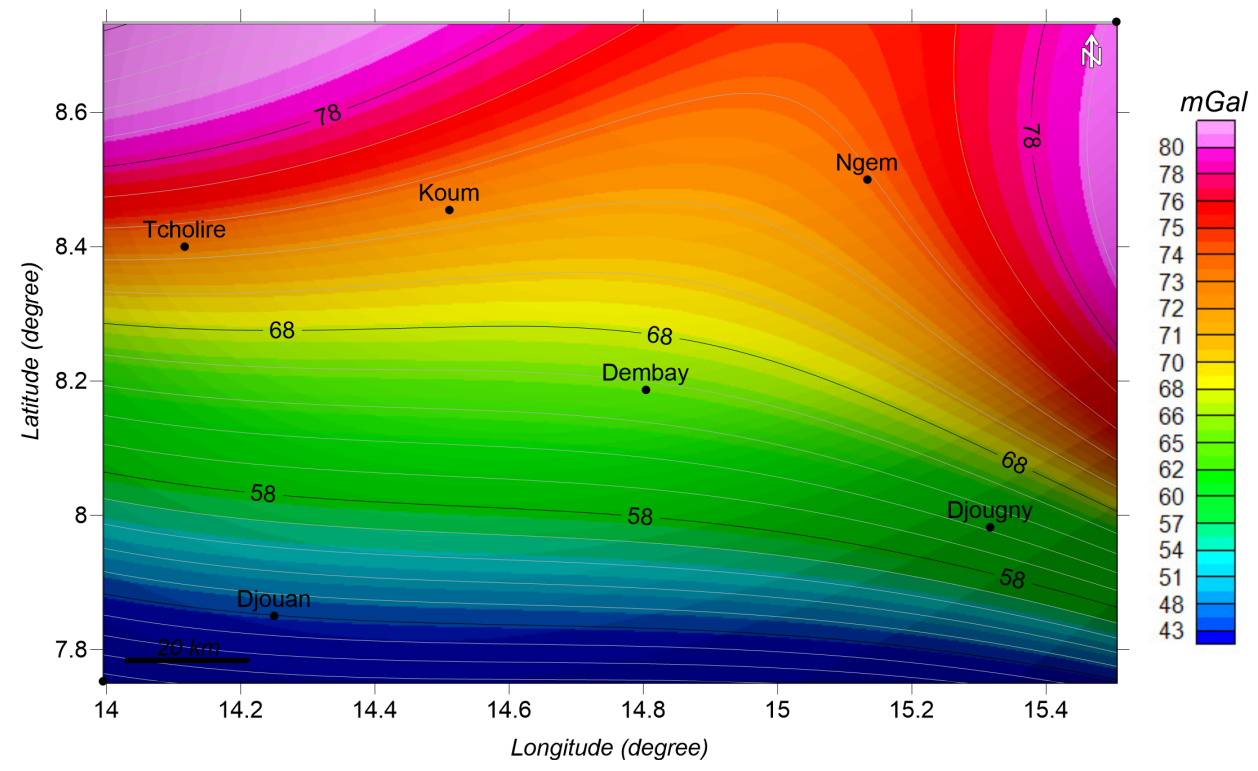

Fig. 5. Regional gravity anomaly map of the Koum area.

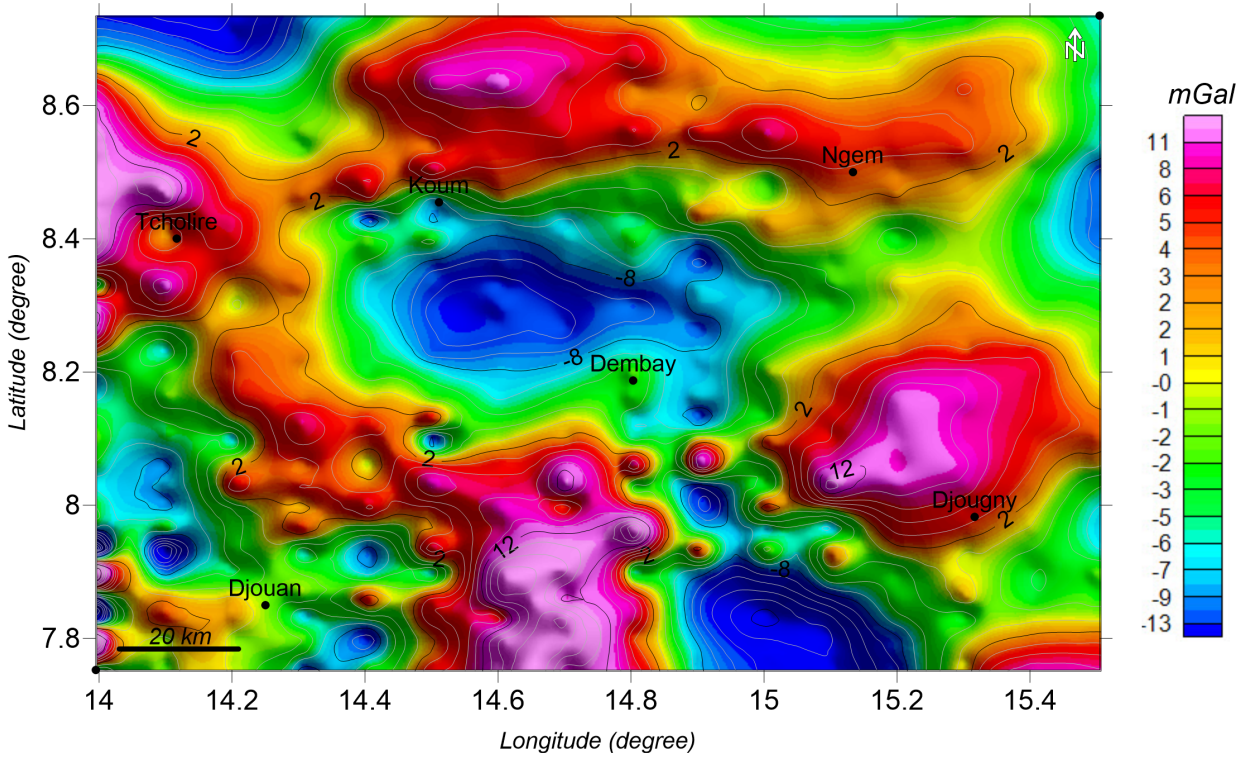

Fig. 6. Residual gravity anomaly map of the Koum area. 


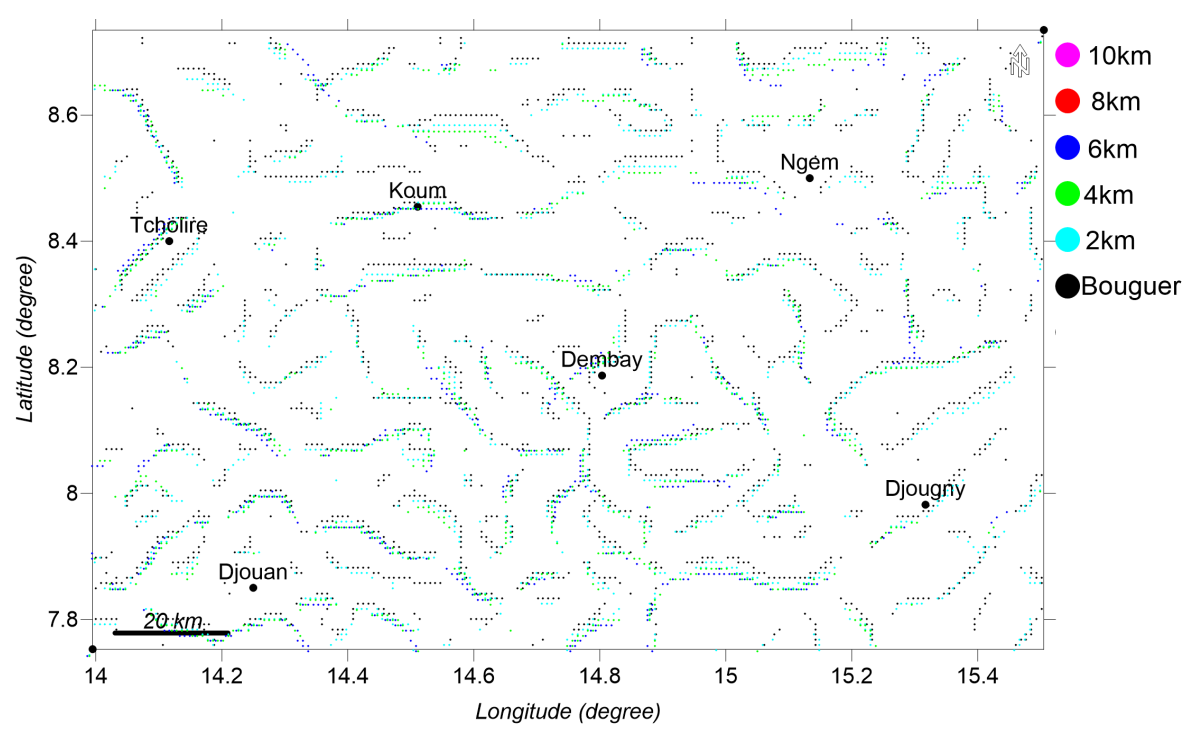

Fig. 7. Horizontal gradient maxima of the residual Bouguer anomaly map and its upward continuations to different heights.

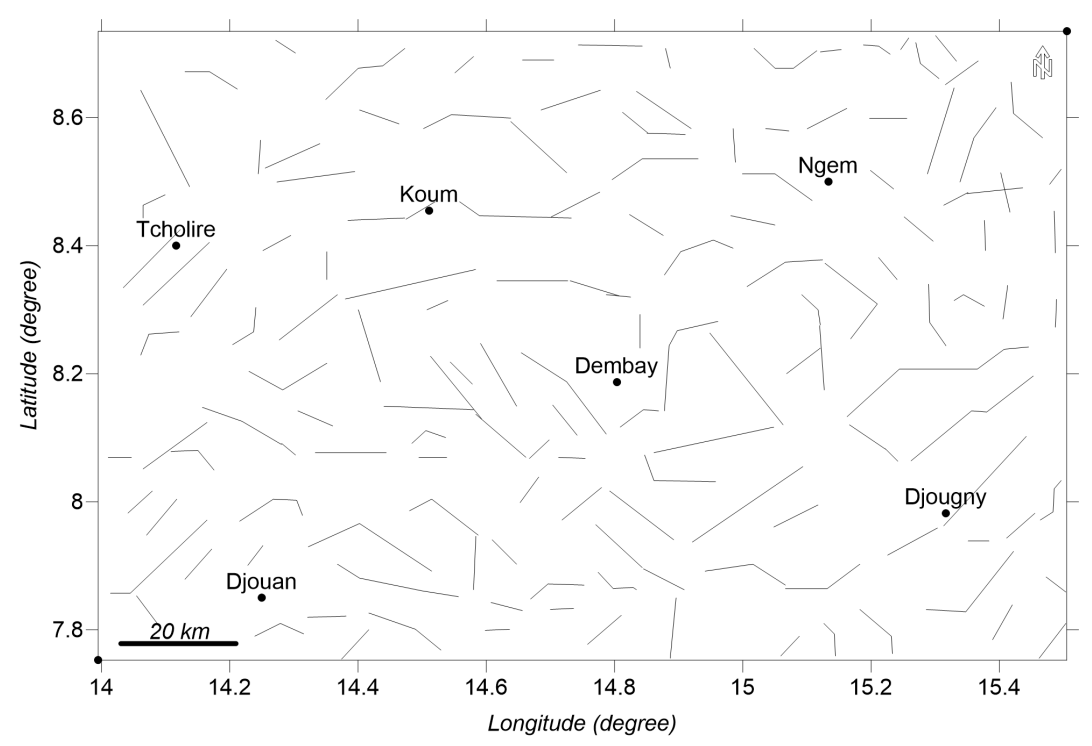

Fig. 8. Lineament map of the study Koum basin area. 


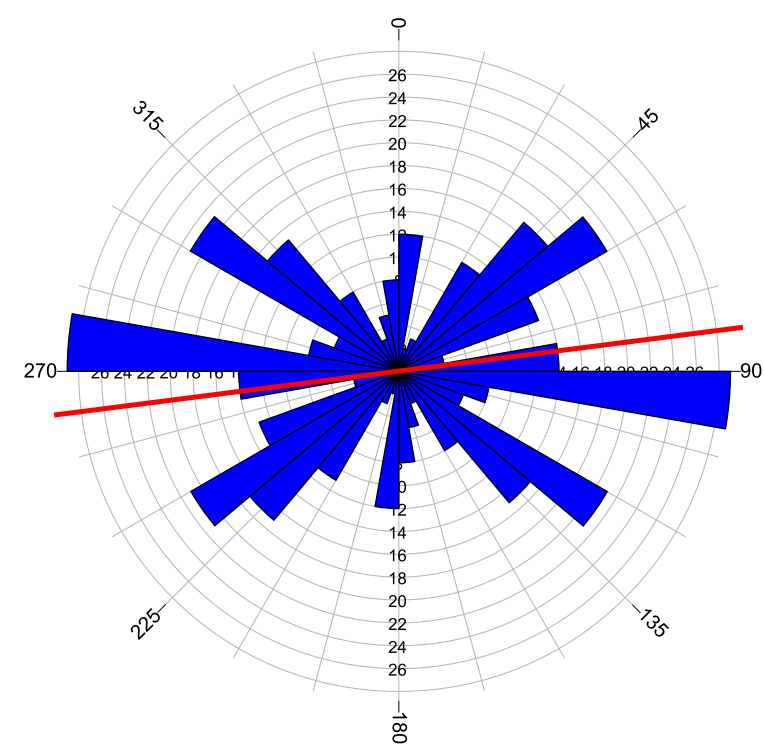

Fig. 9. Tectonic trends derived from Bouguer, regional and residual maps of the study area.

suggest that these faults affect the sediment formations up to $6 \mathrm{~km}$ depth. The faults in the basement terrain have a slightly different orientation with predominant NE-SW trend with few NW-SE and E-W directions. The orientation analysis of gravity lineaments shows various tectonic patterns which were found consistent to a great extent with the regional tectonic grain in the upper Benue through (Ogunmola et al., 2014; 2016).

\section{3D gravity inversion and modelling}

The residual map was used to infer the uppermost crustal density variations in the Koum area by modelling and inversion. The data analysis methodological approach emphasized the integration of geological and geophysical constraints into the forward modeling. For geological constraints, information from the simplified geological map outlining the main superficial lithostratigraphic units was used complemented by borehole data (Nolla Junior et al., 2015). Geophysical constraining focused on direct interpretation of the gravity field (power spectrum analysis). 


\subsection{Power spectrum analysis}

In order to compute the maximum sedimentary thickness in the basin, 2-D spectral analysis was carried out on the residual data over central negative anomaly (Fig. 6). FOURPOT 1.3 software (Pirttijärvi, 2014a) has been used to calculate the radial amplitude spectrum of the residual as a function of radial wave-number $k_{r}$. The residual gravity field values were transformed from the space domain to the frequency domain by means of a Fast Fourier Transform (FFT). Padding and Tapering were applied to remove the Gibbs phenomenon effect as well as ringing and other artifacts in the inverse transformed data and to prevent rapid amplitude changes at the borders of the data area. The power spectrum curve is presented in Fig. 10. On this curve, two straight line segments can be identified and plotted by a least square fitting on the data points. The mean depth of density contrast plane is represented by $h 1$ in the low frequency range associated to deep-seated bodies and $h 2$ in the high frequency range caused by bodies near surface. The mean depth estimates for the deepest discontinuities obtained is $4.567 \mathrm{~km}$. This depth is related to deep seated bedrock underlying the thick sediment

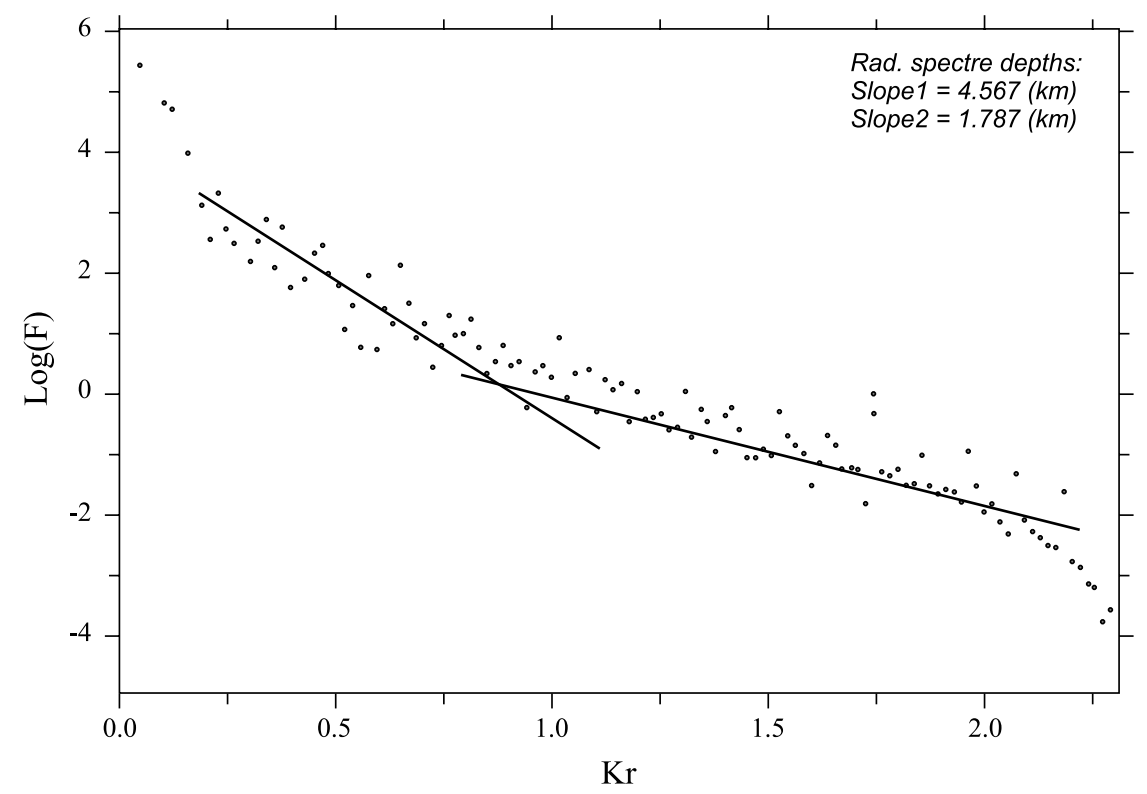

Fig. 10. Power spectrum of the gravity data over the negative central anomaly. 
in the area. This result is consistent with those obtained by Nolla Junior et al. (2015) who estimated the maximum thickness of sediments in the region at about $4.3 \mathrm{~km}$ using field measurements of strikes and dips of beds. The shallowest depths obtained from the second profile is $1.787 \mathrm{~km}$. If we adopt a straightforward approach, this depth should correspond to an intra basin density variation. However, the author of the used software himself (Pirttijärvi, 2014a) advised some reserve since the method of depth determination had not been sufficiently verified. A combination of other geophysical techniques or an a-priori geological information would be necessary in order to justify the interpretation suggested here.

\subsection{D density model}

For three-dimensional gravity modelling and inversion, the software GRABLOX2 2.1a developed by Pirttijärvi (2014b) was used. The main purpose was to optimize the density contrast and/or the shape and dimension of the density variations. GRABLOX computes the synthetic gravity anomaly of a large rectangular super block, which is divided into smaller brick-like volume elements. As the gravity modelling is generally ambiguous, we used depth to the source of the gravity anomaly estimated by spectral analysis in order to constrain gravity modelling. Furthermore, geological constraints (density values) were deduced from the density values (Kamguia et al., 2005) and lithostratigraphic studies (Nolla Junior et al., 2015) published in the area of study and in surrounding areas.

The starting model was constructed by selecting a $100 \times 300 \times 8 \mathrm{~km}$ super block as the area for density modelling (Fig. 11). The block was discretized by grid blocks of dimension $1.44 \mathrm{~km}$ and $1.49 \mathrm{~km}$ in the $\mathrm{E}-\mathrm{W}$ and $\mathrm{N}-\mathrm{S}$ directions. Constant density values were assigned to each minor individual block. Forward calculation was applied on the measured data to have the computed model, and then Occam inversion method was applied to optimize the density contrast model. The RMS error of the resultant model is $0.481 \mathrm{mGal}$ and the maximum difference between the observed and calculated Bouguer data is $16 \mathrm{mGal}$. The resultant density model obtained after 7 iterations is shown in multiple layers (Fig. 12). The main features modeled in the central part of the model are lower density bodies (1) with densities ranging from 2.59 to $2.63 \mathrm{~g} / \mathrm{cm}^{3}$. These bodies are related 


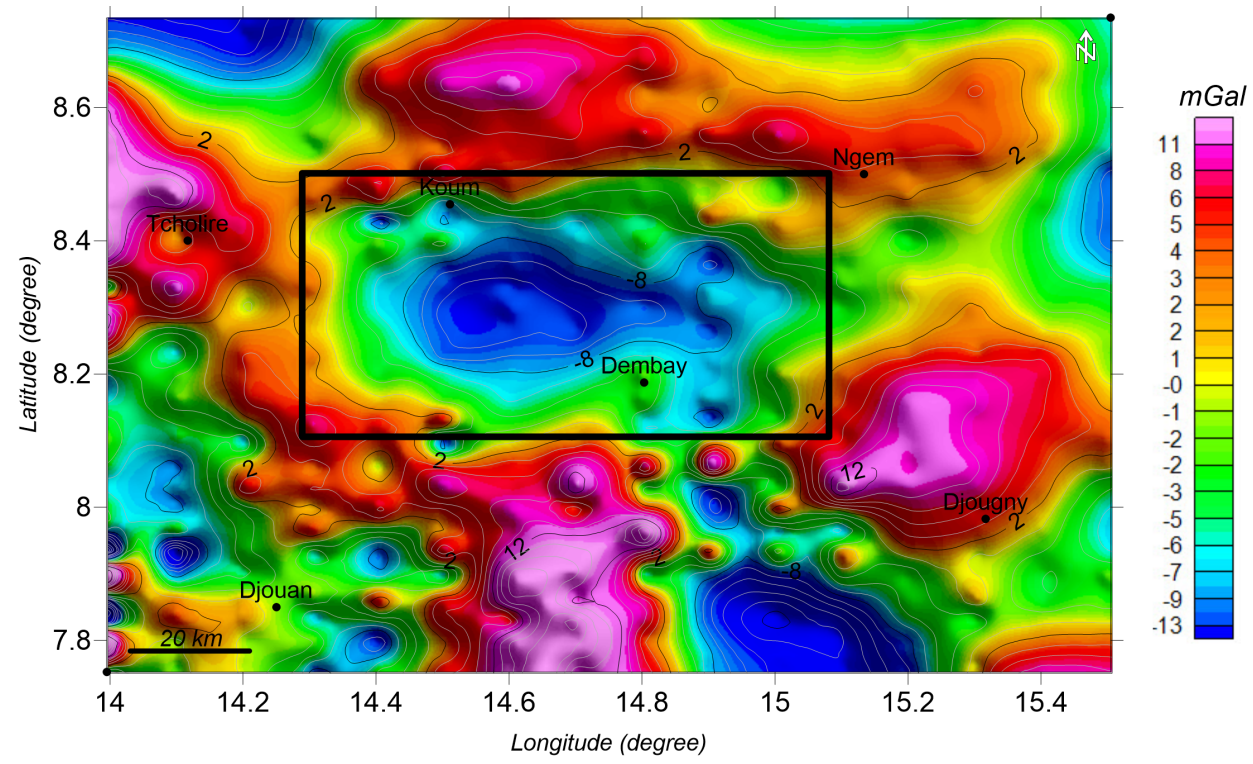

Fig. 11. Plain view of the super block for the comprehensive 3D gravity model of the Koum basin.

to cretaceous sediments. The Koum basin low density zone is characterized by a large horizontal extension in the shallow part and gradually decrease downward in the deeper part. Metamorphic rocks surrounding the basin have densities ranging between 2.64 and $2.7 \mathrm{~g} / \mathrm{cm}^{3}$. Obviously, none of the bodies is expected to really have a homogenous density, because of both the presence of lithologic alternations and the natural increasing of density with depth.

A $2 \mathrm{D}$ cross section A-B through the 3D model (Fig. 13) shows that the sediment thickness under the eastern part of the basin is shallower than in the western part. It is about $1.5 \mathrm{~km}$ beneath the eastern part and reach more than $4 \mathrm{~km}$ in deepest western area.

\section{Conclusion}

In this paper, we attempted to give an insight on the structural setting of the Koum sedimentary basin using WGM2012 gravity data. Regional and 


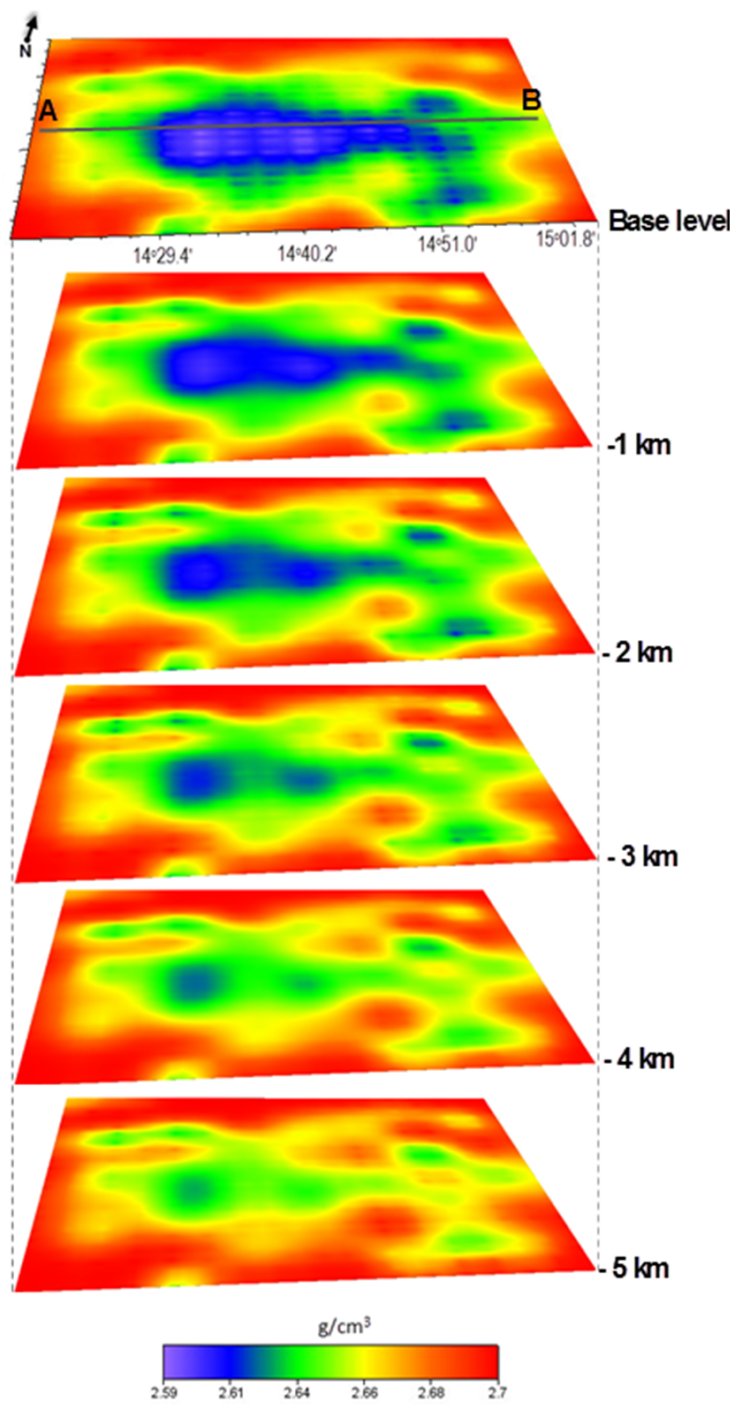

Fig. 12. Resulted 3D gravity inversion maps of the study area.

residual components were separated using the polynomial fitting technique. $3 \mathrm{D}$ Modeling of the gravity indicates the sediment thickness is about $1.5 \mathrm{~km}$ in the eastern part of the basin and gets deeper in the eastern part to reach $4.5 \mathrm{~km}$. Multi-scale analysis was applied to the residual data and results 

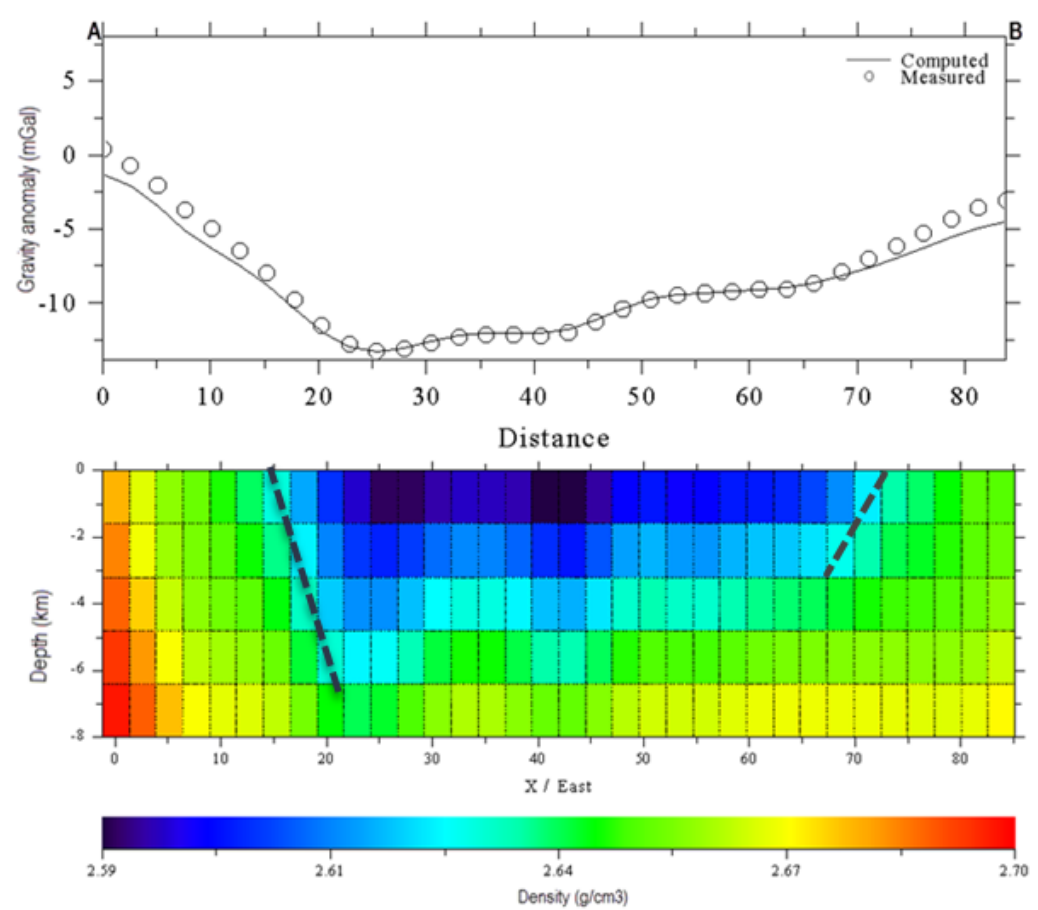

Fig. 13. 2D gravity inversion section across profile A-B.

show that the NW-SE and E-W trends characterize the structure setting of the Koum basin area. The results of this study can be employed as a costeffective tool for delineating preliminary locations for more sophisticated and more expensive geophysical and/or geochemical surveys in the Koum basin.

Acknowledgements. We thank the National Geospatial-Intelligence Agency (NGA) for compiling and making available the dataset used in this work. We are also thankful to Dr. Ján Mikuška for his suggestions to improve the manuscript.

\section{References}

Allix P., Popoff M., 1983: Le Crétacé inférieur de la partie nord-orientale do fossé de la Bénoué (Nigeria) un exemple de relation étroite entre tectonique et sédimentation. 
In: Popoff M. and Tiercelin J. J. (Eds.): Rifts et Fossés Anciens: Tectoniquevolcanisme-sédimentation, apports de l'actualisme. Table ronde du centre National de la recherche Scientifique (Marseille, 1982). Bulletin des Centres de Recherches Exploration-Production Elf-Aquitaine, 7, 1, 349-359 (in French).

Balmino G., Vales N., Bonvalot S., Briais A., 2012: Spherical harmonic modeling to ultra-high degree of Bouguer and isostatic anomalies. Journal of Geodesy, 86, 7, 499-520.

Blakely R. J., 1995: Potential Theory in Gravity and Magnetic Applications: Cambridge, UK, Cambridge University Press, 411 p.

Bonvalot S., Balmino G., Briais A., Kuhn M., Peyrefitte A., Vales N., Biancale R., Gabalda G., Moreaux G., Reinquin F., Sarrailh M., 2012: World Gravity Map, 1:50000000 map, Eds.: BGI-CGMW-CNES-IRD, Paris, CGMW-BGI-CNES-IRD.

Brabant P., 1976: Carte pédologique de reconnaissance, Feuille Rei-Bouba à 1/200000, 107 p. (in French).

Brabant P., Gavaud M., 1985: Les sols et les ressources en Terre du nord-Cameroun. M.E.S.R.E.S., I.R.A., ORSTOM, Not. Exp., 103, 285 p. (in French). (in French).

Brunet M., Coppens Y., Dejax J., Flynn L., Heintz E., Hell J., 1990: Nouveaux mammifčres du Crétacé inférieur du Cameroun, Afrique de l'Ouest. Comptes Rendus Académie de Sciences, Paris, 310, II, 1139-1146 (in French).

Brunet M., Jacobs L., Congleton J., Coppens Y., Dejax J., Flynn L., 1988: Première découverte d'un fragment de mandibule de mammifère dans le Crétacé inférieur d'Afrique (Cameroun, bassin de Koum). Comptes Rendus Académie de Sciences, Paris 307, II, 1675-1680 (in French).

Collignon F., 1968. Gravimétrie et reconnaissance de la République Fédérale du Cameroun ORSTOM Paris, 35 p. (in French).

Duperon-Laudoueneix M., 1991: Les flores ligneuses mésozoïques et cénozoïques d'Afrique nord-équatoriale (Tchad et Cameroun). Thèse doc-d'Etat, Univ. Pièrre et Marie Curie, Paris VI, France, 299 p. (in French).

Kamguia J., Manguelle-Dicoum E., Tabod C. T., Tadjou J. M., 2005: Geological models deduced from gravity data in the Garoua basin, Cameroon. Journal of Geophysics and Engineering, 2, 2, 147-152.

Maurin J. C., Benkhelil J., Robineau B., 1986: Fault rocks of the Kaltungo lineament, NE Nigeria, and their relationship with Benue trough tectonics. Journal of the Geological Society, 143, 587-589.

Nolla Junior D., Hell J. V., Ngos Lii S., Bessong M., Mfoumbeng M. P., Eyong Takem J., Dissombo Edimo A. N., Mbang A. R., Engombi Godlove, Ndjeng E., 2015: Lithostratigraphy of the Koum Basin (Northern Cameroon). International Journal of Multidisciplinary Research and Development, 2, 6, 103-114.

Ogunmola J. K., Ayolabi E. A., Olobaniyi S. B., 2014: Lineament extraction from SPOT 5 and Nigeriasat-x imagery of the upper Benue trough, Nigeria. The International Archives of the Photogrammetry, Remote Sensing and Spatial Information Sciences, Volume XL-1, 2014 ISPRS Technical Commission I Symposium, 17-20, Denver, Colorado, USA. 
Ogunmola J. K., Ayolabi E. A, Olobaniyi S. B., 2016: Structural-depth analysis of the Yola Arm of the Upper Benue Trough of Nigeria using high resolution aeromagnetic data. Journal of African Earth Sciences, 124, 32-43.

Pavlis N. K., Holmes S. A., Kenyon S. C., 2012: The development and evaluation of the Earth gravitational model 2008 (EGM2008). Journal of Geophysical Research, 117, B04406.

Pirttijärvi M., 2014a: FOURPOT Potential field data processing and analysis of using 2-D Fourier transform, User's guide to version 1.3a: https://wiki.oulu.fi/display/ $\sim$ mpi/2D+Fourier+domain+operations .

Pirttijärvi M., 2014b: GRABLOX2 Gravity interpretation and modelling using 3-D block models, user's guide to version 2.1: https://wiki.oulu.fi/display/ mpi/Gravity +inversion+using+block+model+2.

Popoff M., 1988: Du Gondwana à l'Atlantique sud; les connexions du fossé de la Benoué avec les bassins du Nord-Est brésilien jusqu'à l'ouverture du golfe de Guinee au Cretace inferieur. Journal of African Earth Sciences, 7, 2, 409-431.

Schwoerer P., 1965: Carte géologique de reconnaissance à l'échelle du 1/500.000. Notice explicative sur la feuille Garoua Est. Direction des Mines et de la Géologie du Cameroun (éd.), Yaoundé, 49 p. (in French).

Tokam A. P., Tabod C. T., Nyblade A. A., Jordi J., Wiens D. A., Pasyanos M. E., 2010: Structure of the Crust Beneath Cameroon, West Africa, from the Joint Inversion of Rayleigh Wave Group Velocities and Receiver Functions. Geophysical Journal International, 183, 1061-1076.

Zeng H., 1989: Estimation of the Degree of Polynomial Fitted to Gravity Anomalies and Its Applications. Geophysical Prospecting, 37, 959-973. 